\title{
Scanning Electron Microscopy of Leaves and the Leave Galls from Quercus arizonica Sargent (Fagaceae).
}

C. Scareli-Santos*, M. L. Mondragón-Sánchez ${ }^{* *}$, K. Oyama***

* DERN - Instituto de Ecología, UNAM, Antigua Carretera a Pátzcuaro, 8701 C. P. 58190, Morelia, Michoacán, México E-mail: scareli@oikos.unam.mx

** Instituto Tecnológico de Morelia, Mex. SEM Lab. Email: mlms@prodigy.net.mx *** Instituto de Ecología, UNAM, Campus Morelia, Michoacán, México E-mail: akoyama@oikos.unam.mx

The galls are structures originated because of the pathologic development of cells or tissues from plants due to the influence of parasites organisms [1]. Some vegetal taxonomic groups present a rich fauna of galling, and others present low percent of infestation or never get infest. The genus Baccharis (Asteraceae) is an excellent example, for the neotropical flora, since they present a high richness of insect galls [2], on the other hand for the mild regions Quercus (Fagaceae), is one of the most representatives genus $[3,4]$. The main objective of this work was to characterize the leaves and the leave galls from $Q$. arizonica. The samples, coming from Durango (Mexico), were prepared for the morphological analysis [5] and observed in a Scanning Electron Microscope (Jeol-5910LV). In the leaves were observed stellate trichomas in the abaxial surface (10 arms, Fig. 1A) and in the adaxial ( 8 arms, Fig.1D). The abaxial surface presented epicuticular wax in plaques and stomatas (Figs. 1B and 1C), while in the adaxial surface the wax presented a crust type; there were not observed stomatas. (Figs. $1 \mathrm{E}$ and $1 \mathrm{~F}$ ). The galls from $Q$. arizonica occur in the abaxial surface of the leaves, showing a conical shape, with $4 \mathrm{~mm}$ high and brown color (Fig. 1G). Externally, the galls presented glandular trichomas (Figs. 1H and 1I) covered with crust type wax similar to those that occurs in healthy leaves (Figs.1I and 1J). Internally, the galls present a cavity divided in 2 parts, the larval chamber and an exit channel (Figs. 1K and 1L); presenting trichomas similar to those observed externally to the gall (Figs. $1 \mathrm{M}$ and $1 \mathrm{~N}$ ). The tissues observed, from the one closer to the larval chamber to the external one, were nutritive (Figs. 1O and 1P), parenchymatic (Figs. 1O and 1P) and epidermis (Fig.1R). The occurrence of different trichomas and the galls tissue distribution were corroborated with the observations in a previous study [6].

References

[1] M. S. Mani, Ecology of Plant Galls, W. Junk, The Hague, 1964.

[2] Fernandes et al., Tropical Zoology 9 (1996) 315.

[3] R. J. Gagné, The Plant-Feeding Gall Midges of North America. Cornell University Press, Ithaca, 1989.

[4] S. E. Hartley, Oecologia 113: (1998) 492.

[5] M. A. Hayat, Principles and Techniques of Scanning Electron Microscopy Biological Applications, New York, USA: Van Nostrand Reinhold Company,1983. [6] Scareli-Santos et al. Phytomorphology 49 (1999) 29.

[7] The authors thank M. L. Herrera Arroyo, M. A. Pérez Pérez and J. de J. Barreto. The study was financially supported by CONACYT-Mexico (Ref: $38550-\mathrm{V}$ ). 

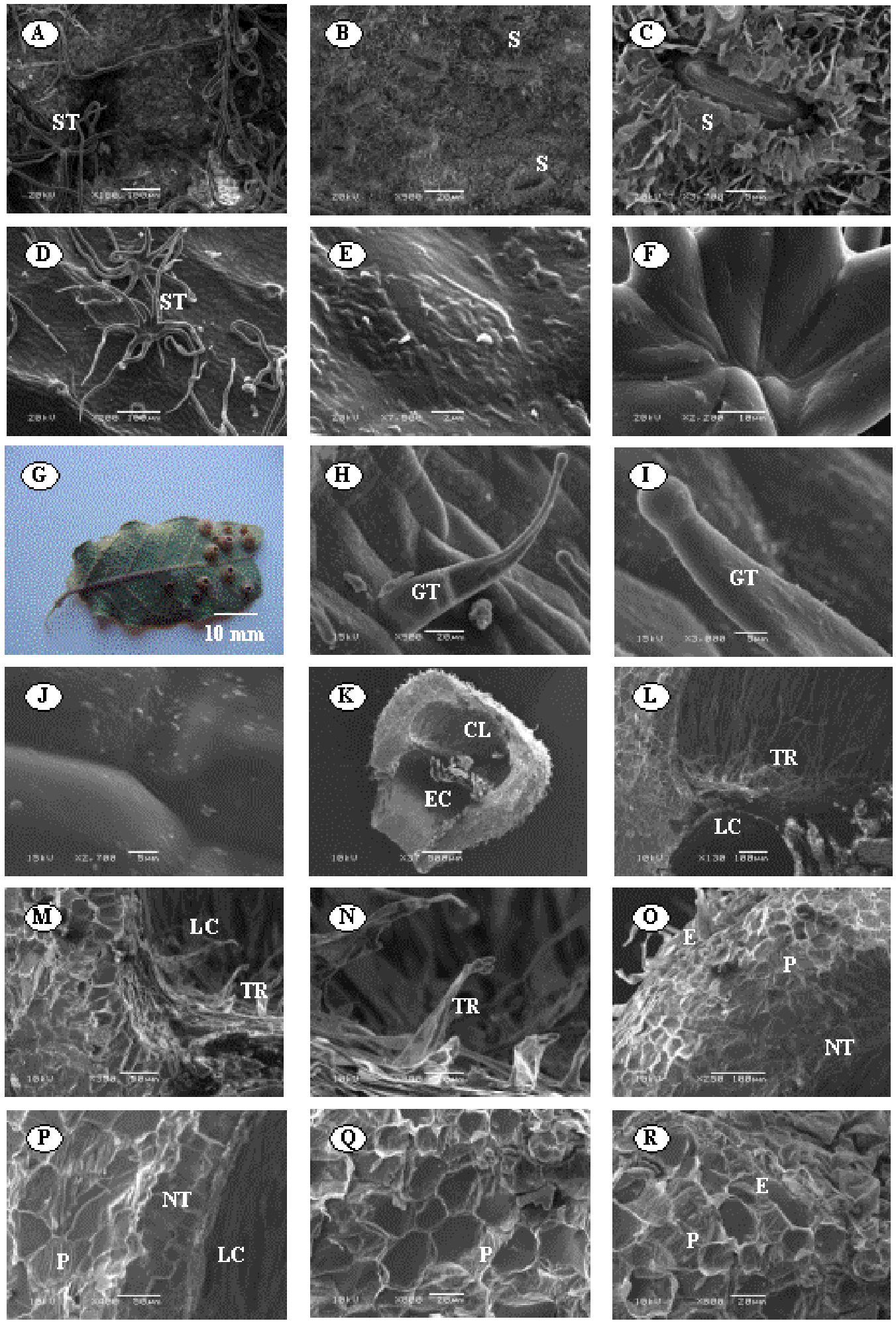

Fig. 1. Scanning Electron Microscopy of leaves of $Q$ arizonica (Fagaceae) $1 \mathrm{~A}-1 \mathrm{C}$ abaxial surface and $1 \mathrm{D}-1 \mathrm{~F}$ adaxial surface; $1 \mathrm{G}$ external view of the conical gall of $Q$ arizonica; Scanning Electron Microscopy of the leaves galls of $Q$ arizonica $1 \mathrm{H}-1 \mathrm{~J}$ externa seccion, $\mathrm{Fig} 1 \mathrm{~K}-1 \mathrm{R}$ interna seccion.

$\mathrm{ST}=$ stellate trichoma, GT = glandular trichoma $\mathrm{S}=$ stomata, LC =larval chamber, $\mathrm{EC}=$ exit chanel, $\mathrm{NT}=$ nutritive tissue, $\mathrm{P}=$ parenchyma, $\mathrm{E}=$ epidermis. 